\title{
Relating GPCRs pharmacological space based on ligands chemical similarities
}

\author{
Alexios Koutsoukas, Rubben Torella, George Drakakis, Andreas Bender, ${ }^{*}$ Robert C Glen ${ }^{*}$ \\ From 8th German Conference on Chemoinformatics: 26 CIC-Workshop \\ Goslar, Germany. 11-13 November 2012
}

G protein-coupled receptors (GPCRs) are a major family of membrane receptors in eukaryotic cells and play a crucial role in various biological processes. They represent a family of protein targets with significant therapeutic value, and accordingly more than $30 \%$ of prescription drugs are GPCR ligands [1].

Extending previous attempts to map the pharmacological space solely based on ligand chemical similarity, $[2,3]$ we in this work relate GPCRs pharmacological space by combining structure-activity data from ChEMBL and WOMBAT that covers 167 human GPCRs and 67k ligands. By including more information from the ligand side in our analysis than previous studies, we hence attempted to construct a more detailed map of the pharmacological space. A statistical approach similar to the "Similarity Ensemble Approach" (SEA)[2] was implemented to relate proteins based on the chemical similarity of their ligands, and to rank the significance of the resulting similarity scores. A prospective external validation dataset was then employed to confirm new relationship between ligands and different GPCRs, providing mechanistic evidence for observed side effects of drugs in the dataset.

The results of the study aim to contribute to a better understanding of the overlap of GPCRs in chemical space, and to the cross-reactivity observed even among distant biological targets, as defined by their sequence similarities [4] . Relevant applications range from understanding drug side effects to the design of drugs with a desired polypharmacological profile.

Published: 22 March 2013

* Correspondence: ab454@cam.ac.uk; rcg28@cam.ac.uk

Unilever Centre for Molecular Informatics, Department of Chemistry, Lensfield Road, University of Cambridge, Cambridge, CB2 1EW, UK
References

1. Erguner B, Hattori M, Goto S, Kanehisa M: Characterizing Common Substructures of Ligands for GPCR Protein Subfamilies. Genome Inf 2010, 24:31-41.

2. Keiser MJ, Roth BL, Armbruster BN, Ernsberger P, Irwin JJ, Shoichet BK: Relating Protein Pharmacology by Ligand Chemistry. Nat Biotechnol 2007, 25:197-206.

3. Paolini GV, Shapland RHB, van Hoorn WP, Mason JS, Hopkins AL: Global Mapping of Pharmacological Space. Nat Biotechnol 2006, 24:805-815.

4. van Der Horst E, Peironcely JE, ljzerman AP, Beukers MW, Lane JR, van Vlijmen HWT, Emmerich MTM, Okuno Y, Bender A: A Novel Chemogenomics Analysis of G Protein-Coupled Receptors (GPCRs) and Their Ligands: a Potential Strategy for Receptor De-Orphanization. BMC Bioinformatics 2010, 11:316.

doi:10.1186/1758-2946-5-S1-P26

Cite this article as: Koutsoukas et al:: Relating GPCRs pharmacological space based on ligands chemical similarities. Journal of Cheminformatics 2013 5(Suppl 1):P26.

\section{Publish with ChemistryCentral and every scientist can read your work free of charge \\ “Open access provides opportunities to our colleagues in other parts of the globe, by allowing anyone to view the content free of charge." \\ W. Jeffery Hurst, The Hershey Company. \\ - available free of charge to the entire scientific community \\ - peer reviewed and published immediately upon acceptance \\ - cited in PubMed and archived on PubMed Central \\ - yours - you keep the copyright \\ Submit your manuscript here: \\ http://www.chemistrycentral.com/manuscript/

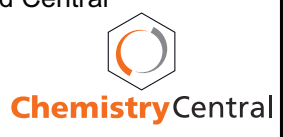

